\title{
Article \\ A Gadolinium(III) Complex Based on the Thymine Nucleobase with Properties Suitable for Magnetic Resonance Imaging
}

\author{
Marta Orts-Arroyo ${ }^{1}$, Amadeo Ten-Esteve ${ }^{2}\left(\mathbb{D}\right.$, Sonia Ginés-Cárdenas ${ }^{2}$, Isabel Castro ${ }^{1}\left(\mathbb{D}\right.$, Luis Martí-Bonmatí ${ }^{2, *(1)}$ \\ and José Martínez-Lillo ${ }^{1, * \mathbb{D}}$ \\ 1 Instituto de Ciencia Molecular (ICMol), Universitat de València, c/Catedrático José Beltrán 2, Paterna, \\ 46980 Valencia, Spain; marta.orts-arroyo@uv.es (M.O.-A.); isabel.castro@uv.es (I.C.) \\ 2 Radiology Department and Biomedical Imaging Research Group (GIBI230), La Fe University and Polytechnic \\ Hospital and La Fe Health Research Institute, 46026 Valencia, Spain; ten_ama@gva.es (A.T.-E.); \\ soniagibi230@gmail.com (S.G.-C.) \\ * Correspondence: marti_lui@gva.es (L.M.-B.); f.jose.martinez@uv.es (J.M.-L.); Tel.: +34-9635-44460 (J.M.-L.)
}

check for updates

Citation: Orts-Arroyo, M.; Ten-Esteve, A.; Ginés-Cárdenas, S.; Castro, I.; Martí-Bonmatí, L.; Martínez-Lillo, J. A Gadolinium(III) Complex Based on the Thymine Nucleobase with Properties Suitable for Magnetic Resonance Imaging. Int. J. Mol. Sci. 2021, 22, 4586. https:// doi.org/10.3390/ijms22094586

Academic Editor: Diego Tesauro

Received: 25 March 2021

Accepted: 23 April 2021

Published: 27 April 2021

Publisher's Note: MDPI stays neutral with regard to jurisdictional claims in published maps and institutional affiliations.

Copyright: (c) 2021 by the authors. Licensee MDPI, Basel, Switzerland. This article is an open access article distributed under the terms and conditions of the Creative Commons Attribution (CC BY) license (https:/ / creativecommons.org/licenses/by/ $4.0 /)$.

\begin{abstract}
The paramagnetic gadolinium(III) ion is used as contrast agent in magnetic resonance (MR) imaging to improve the lesion detection and characterization. It generates a signal by changing the relaxivity of protons from associated water molecules and creates a clearer physical distinction between the molecule and the surrounding tissues. New gadolinium-based contrast agents displaying larger relaxivity values and specifically targeted might provide higher resolution and better functional images. We have synthesized the gadolinium(III) complex of formula $\left[\mathrm{Gd}(\text { thy })_{2}\left(\mathrm{H}_{2} \mathrm{O}\right)_{6}\right]\left(\mathrm{ClO}_{4}\right)_{3} \cdot 2 \mathrm{H}_{2} \mathrm{O}$ (1) [thy = 5-methyl-1H-pyrimidine-2,4-dione or thymine], which is the first reported compound based on gadolinium and thymine nucleobase. 1 has been characterized through UV-vis, IR, SEM-EDAX, and single-crystal $\mathrm{X}$-ray diffraction techniques, and its magnetic and relaxometric properties have been investigated by means of SQUID magnetometer and MR imaging phantom studies, respectively. On the basis of its high relaxivity values, this gadolinium(III) complex can be considered a suitable candidate for contrast-enhanced magnetic resonance imaging.
\end{abstract}

Keywords: thymine; gadolinium; contrast agent; magnetic resonance; metal complexes; crystal structure; relaxivity

\section{Introduction}

Thymine is one of the four natural nitrogen bases that are precursors and part of the structure of the deoxyribonucleic acid (DNA) macromolecule [1,2]. This pyrimidine base has been widely studied, in part because of the common mutations of DNA caused when adjacent thymines are irradiated by UV light and are dimerized, generating the well-known thymine dimers [2,3]. Furthermore, considerable effort has also been devoted to the rational design of drugs that might selectively inhibit thymine biosynthesis, thereby blocking DNA replication, especially in rapidly dividing malignant cells [2].

In comparison with other natural nucleobases, the coordination chemistry of thyminebased metal complexes has been much less investigated. Most of the thymine-containing complexes have been prepared with the nucleobase in the form of thyminate anion, that is, releasing one or two protons of its $\mathrm{N}-\mathrm{H}$ groups, whereas the reported examples obtained with the thymine molecule acting through its carbonyl groups as a neutral ligand toward the metal are much scarcer [4-7]. In that respect, theoretical studies have been performed on metal clusters to investigate the preferential binding sites of the thymine molecule [8].

There exist some published thymine-based complexes that exhibit singular properties, as, for instance, the $\mathrm{Ru}^{\mathrm{II}}$-thymine complex $\left[\mathrm{Ru}\left(\mathrm{PPh}_{3}\right)_{2}\right.$ (thy) $\left.(\mathrm{bpy})\right] \mathrm{PF}_{6}\left[\right.$ where $\mathrm{PPh}_{3}=$ triphenylphosphine and bpy $=2,2^{\prime}$-bipyridine], which is a potent cytotoxic agent with the ability to bind to DNA, inducing apoptotic cell death in human colon carcinoma [6,7]. Thymine has also shown to be a highly specific ligand toward $\mathrm{Hg}^{\mathrm{II}}$ metal ion $[9,10]$. The 
<smiles>Cc1c[nH]c(=O)[nH]c1=O</smiles>

(a) discovery of the linear thymine-HgII-thymine structure, which affords a high stabilization of thymine-thymine pairs in DNA, has led to the designing and development of recent thymine-based sensors [11-13].

Regarding lanthanide complexes, only two structures based on thyminate anion have been published so far, namely, the heteropolynuclear complexes of general formula $\left[\left\{\mathrm{Cp}^{*} \mathrm{Rh}^{\mathrm{III}}(\mu \text {-thym }\}_{4}\left\{\mathrm{Ln}^{\mathrm{III}}\left(\mathrm{NO}_{3}\right)_{2}\right\}\right]^{+}\right.$, where $\mathrm{Ln}=\mathrm{Dy}{ }^{\mathrm{III}}$ and $\mathrm{Er}^{\mathrm{III}}$, which form cationic metallacalix[4]arene-type systems [14]. Hence, no crystal structure of gadolinium complex based on thymine has been reported up to date.

As a continuation of our interest in investigating biomolecule-based complexes [15-20], herein we report the synthesis and characterization of a new gadolinium(III) complex of formula $\left[\mathrm{Gd}(\text { thy })_{2}\left(\mathrm{H}_{2} \mathrm{O}\right)_{6}\right]\left(\mathrm{ClO}_{4}\right)_{3} \cdot 2 \mathrm{H}_{2} \mathrm{O}(\mathbf{1})$ [thy = thymine], which exhibits a linearly disposed thymine-Gd ${ }^{\mathrm{III}}$-thymine structure (Figure 1 and Figure S1). 1 displays the first reported crystal structure based on gadolinium and thymine and is a suitable candidate for contrast-enhanced magnetic resonance (MR) imaging applications.

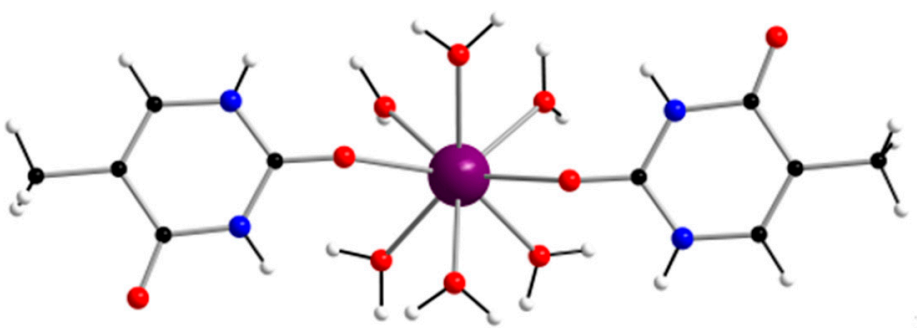

(b)

Figure 1. (a) Molecular structure of the thymine nucleobase (thy); (b) Mononuclear $\left[\mathrm{Gd}(\text { thy })_{2}\left(\mathrm{H}_{2} \mathrm{O}\right)_{6}\right]^{3+}$ complex in 1. $\mathrm{ClO}_{4}{ }^{-}$anions and non-coordinated water molecules have been omitted for clarity. Color code: purple, Gd; red, O; blue, N; black, $\mathrm{C}$; white, $\mathrm{H}$.

\section{Results and Discussion}

\subsection{Synthetic Procedure}

Compound 1 was prepared from a mixture of $\mathrm{Gd}_{2} \mathrm{O}_{3}$ and thymine, which reacted in an aqueous suspension acidulated with perchloric acid, and was stirred at $60{ }^{\circ} \mathrm{C}$ for $1 \mathrm{~h}$. The resulting solution was left to evaporate at room temperature for 1 week, thus generating colorless parallelepipeds of $\mathbf{1}$. Once synthesized, $\mathbf{1}$ is air-stable over a period of several days. In order to study its stability further, electronic absorption spectra of $\mathbf{1}$ were collected both in solid state and in aqueous solution (Figure 2 and Figure S2). Remarkably, the two spectra show the same absorption bands and different ones to that of the free thymine ligand (Figure S2), with this fact indicating the stability of $\mathbf{1}$ in aqueous solution (Figure 2a). SEM-EDAX analysis gave a molar ratio of $1: 3$ for the $\mathrm{Gd} / \mathrm{Cl}$ relation in $\mathbf{1}$ (Figure $2 \mathrm{~b}$ ).

\subsection{IR Spectroscopy}

The infrared spectra of $\mathbf{1}$ and free thymine ligand are given in Figure S3. The infrared spectrum of thymine has been studied in detail in previous works [21,22], nevertheless, it has been included here just for comparison. The most interesting feature that is observed are the main vibrational bands associated to the two $\mathrm{C}=\mathrm{O}$ groups, whose values for the free thymine ligand are 1735 and $1679 \mathrm{~cm}^{-1}$, respectively [21,22]. For $\mathbf{1}$, these vibrational bands are observed at 1747 and $1679 \mathrm{~cm}^{-1}$ (Figure S3), which is consistent with the coordination of the ligand through of only one $\mathrm{C}=\mathrm{O}$ group [23].

The main vibrational bands associated to perchlorate anion are observed at 1145, 1112, and $1089 \mathrm{~cm}^{-1}$, which indicate the presence of this anion counterbalancing the positive charges of the cationic $\left[\mathrm{Gd}(\text { thy })_{2}\left(\mathrm{H}_{2} \mathrm{O}\right)_{6}\right]^{3+}$ complex of $\mathbf{1}$ (Figure S3). 


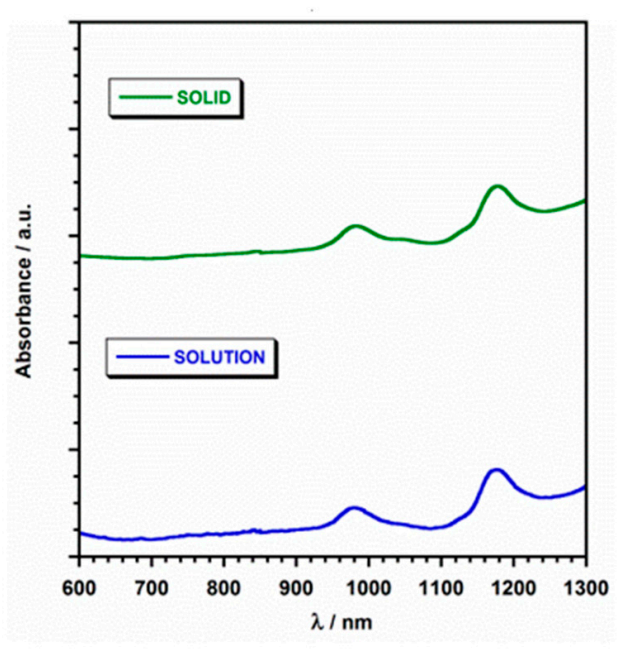

(a)

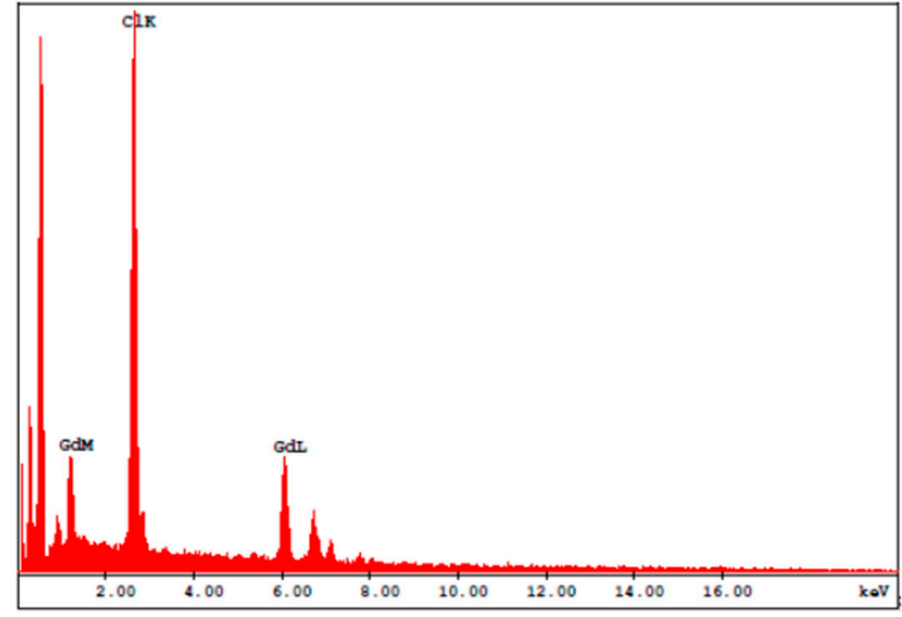

(b)

Figure 2. (a) Electronic absorption spectra from samples of compound $\mathbf{1}$ in solid state (top) and in aqueous solution (bottom); (b) SEM-EDAX spectrum for compound 1.

\subsection{Description of the Crystal Structure}

Crystal data and structure refinement parameters are summarized in Table 1. Compound 1 crystallizes in the monoclinic system with space group $P 2_{1} / c$. Its crystal structure is made up of $\left[\mathrm{Gd}(\text { thy })_{2}\left(\mathrm{H}_{2} \mathrm{O}\right)_{6}\right]^{3+}$ cations, $\mathrm{ClO}_{4}{ }^{-}$anions, and water molecules of crystallization, which are held together mainly by electrostatic forces and $\mathrm{H}$-bonding interactions. A $\left[\mathrm{Gd}(\text { thy })_{2}\left(\mathrm{H}_{2} \mathrm{O}\right)_{6}\right]^{3+}$ cation, three $\mathrm{ClO}_{4}{ }^{-}$anions, and two non-coordinating water molecules are present in the asymmetric unit of $\mathbf{1}$.

Table 1. Summary of the crystal data and structure refinement parameters for $\mathbf{1}$.

\begin{tabular}{|c|c|}
\hline Compound & 1 \\
\hline CCDC & 2009091 \\
\hline Formula & $\mathrm{C}_{10} \mathrm{H}_{28} \mathrm{~N}_{4} \mathrm{O}_{24} \mathrm{Cl}_{3} \mathrm{Gd}$ \\
\hline$M_{\mathrm{r}} / \mathrm{g} \mathrm{mol}^{-1}$ & 851.96 \\
\hline Crystal system & Monoclinic \\
\hline Space group & $P 2_{1} / c$ \\
\hline$a / \AA$ & $13.192(1)$ \\
\hline$b / \AA$ & $9.901(1)$ \\
\hline$c / \AA$ & $20.985(1)$ \\
\hline$\alpha /{ }^{\circ}$ & 90 \\
\hline$\beta /{ }^{\circ}$ & $95.18(1)$ \\
\hline$\gamma /{ }^{\circ}$ & 90 \\
\hline$V / \AA^{3}$ & $2729.8(2)$ \\
\hline Z & 4 \\
\hline$D_{\mathrm{c}} / \mathrm{g} \mathrm{cm}^{-3}$ & 2.073 \\
\hline$\mu\left(\mathrm{Mo}-\mathrm{K}_{\alpha}\right) / \mathrm{mm}^{-1}$ & 2.832 \\
\hline Goodness-of-fit on $F^{2}$ & 1.081 \\
\hline$R_{1}[I>2 \sigma(I)] /$ all & $0.0280 / 0.0325$ \\
\hline$w R_{2}[I>2 \sigma(I)] /$ all & $0.0703 / 0.0733$ \\
\hline
\end{tabular}

The Gd ${ }^{\mathrm{III}}$ ion in $\mathbf{1}$ is eight-coordinate and bonded to eight oxygen atoms, two oxygen atoms from carbonyl groups of two neutral thymine ligands, and six oxygen atoms of six water molecules (Figure 1). Given the neutral nature of the thymine molecule, coordination through the $\mathrm{O}(1)$ and $\mathrm{O}(3)$ atoms is expected (Figures $\mathrm{S} 1$ and S4). The average value of the Gd-O bond lengths [2.381(1) $\AA$ ] is somewhat shorter than that of the Gd-O $\mathrm{O}_{\text {water }}$ bond lengths [2.390(1) $\AA]$ (Table S1). The O-Gd-O bond angles show values covering the 
range of $70.24(6)-148.57(7)^{\circ}$. These values are in agreement with those reported for other species with a similar Gd ${ }^{I I I}$ environment [24-26]. In 1, the thymine molecules are planar and form an angle between them of ca. $7.8(1)^{\circ}$ with an intramolecular thymine-thymine separation of ca. $4.08 \AA$, which corresponds to the $\mathrm{O}(1) \cdots \mathrm{O}(3)$ distance. The $\mathrm{C}-\mathrm{C}, \mathrm{C}-\mathrm{N}$, and $\mathrm{C}-\mathrm{O}$ bond lengths agree with those found in the literature for the thymine molecule (Table S1) [27].

In the crystal packing of $\mathbf{1}$, adjacent $\left[\mathrm{Gd}(\text { thy })_{2}\left(\mathrm{H}_{2} \mathrm{O}\right)_{6}\right]^{3+}$ cations are connected through $\mathrm{H}-$ bonding interactions that occur between thymine pairs, linking them into chains $[\mathrm{N}(3) \cdots \mathrm{O}(4 \mathrm{a})$ $=2.763(3) \AA$ and $\mathrm{O}(2) \cdots \mathrm{N}(10 \mathrm{a})=2.785(3) \AA ;(\mathrm{a})=\mathrm{x}, \mathrm{y}-1, \mathrm{z}]$, which grow along the $b$ crystallographic axis (Figure S5). These chains are separated from each other through perchlorate anions, which interact with coordinated water molecules by means of $\mathrm{H}$-bonding interactions involving the following set of atoms: $\mathrm{O}(3 \mathrm{w}) \cdots \mathrm{O}(11 \mathrm{~b})[2.944(3) \AA$; $(\mathrm{b})=-\mathrm{x}+1$, $-\mathrm{y}+1,-\mathrm{z}+1], \mathrm{O}(4 \mathrm{w}) \cdots \mathrm{O}(10 \mathrm{~b})[2.870(3) \AA], \mathrm{O}(4 \mathrm{w}) \cdots \mathrm{O}(15 \mathrm{c})[2.847(3) \AA$ $-\mathrm{z}+3 / 2]$, and $\mathrm{O}(5 \mathrm{w}) \cdots \mathrm{O}(12)[2.713(3) \AA]$ (Figure 3). The chains based on $\left[\mathrm{Gd}(\text { thy })_{2}\left(\mathrm{H}_{2} \mathrm{O}\right)_{6}\right]^{3+}$ cations are arranged forming a herringbone type structure, generating thymine planes that exhibit an angle of ca. $64(1)^{\circ}$ (Figure 3b). The shortest Gd $\cdots$ Gd separation is 8.256(1) $\AA$ $[\mathrm{Gd}(1) \cdots \mathrm{Gd}(1 \mathrm{~d})$ distance; $(\mathrm{d})=-\mathrm{x},-\mathrm{y}+1,-\mathrm{z}+1]$. A supramolecular network is generated by additional $\mathrm{H}$-bonding interactions involving coordinated and non-coordinated water molecules, along with weaker $\mathrm{C}-\mathrm{H} \cdots \mathrm{O}$ interactions [the average value of the $\mathrm{C} \cdots \mathrm{O}$ distance being ca. $3.34 \AA$ for $\mathrm{C}(13) \cdots \mathrm{O}(16), \mathrm{C}(6) \cdots \mathrm{O}(5 \mathrm{~d})$ and $\mathrm{C}(13) \cdots \mathrm{O}(11 \mathrm{e}) ;(\mathrm{e})=-\mathrm{x}+1, \mathrm{y}+1 / 2$, $-z+3 / 2]$, which contribute to stabilizing the crystal structure in $\mathbf{1}$ (Table 2).

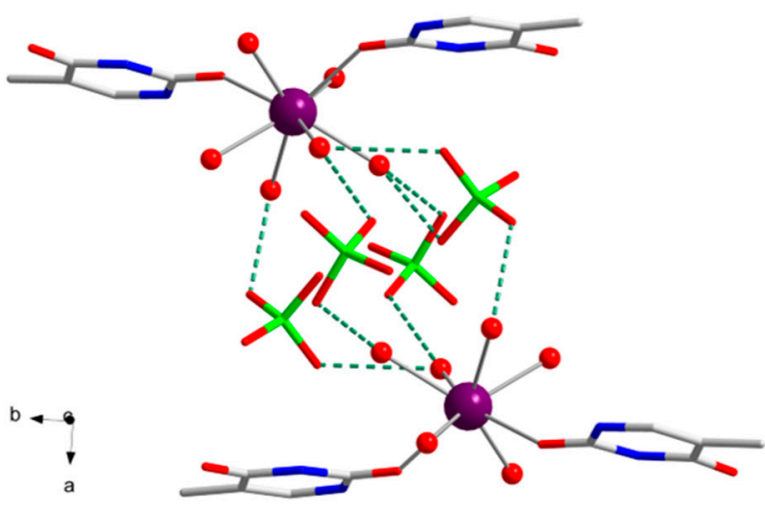

(a)

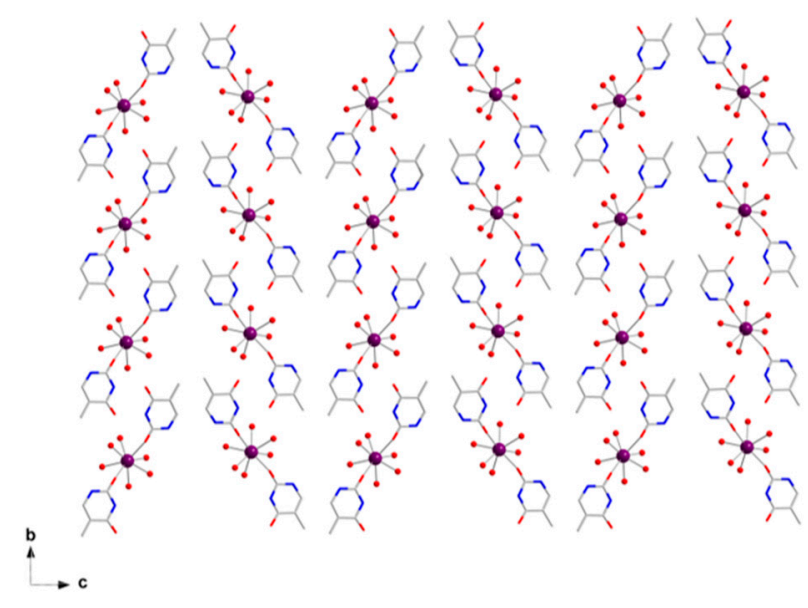

(b)

Figure 3. (a) View along the crystallographic $c$ axis of the H-bonding interactions (green dashed lines) between perchlorate anions (capped sticks model) and $\left[\mathrm{Gd}(\text { thy })_{2}\left(\mathrm{H}_{2} \mathrm{O}\right)_{6}\right]^{3+}$ cations in $\mathbf{1}$. For the sake of clarity, $\mathrm{H}$ atoms are omitted and only coordinated water molecules are shown. Color code: purple, Gd; green, Cl; red, O; blue, N; grey, C; (b) View along the crystallographic $a$ axis of the herringbone type structure of $\mathbf{1}$. $\mathrm{H}$ atoms, perchlorate anions, and non-coordinating water molecules have been omitted for clarity. Color code: purple, Gd; red, O; blue, N; grey, C.

To further analyze the coordination environment and geometry of the Gd ${ }^{\mathrm{III}}$ ion in $\mathbf{1}$, the SHAPE program was used [28]. In $\mathbf{1}$, the single $\mathrm{Gd}^{\mathrm{III}}$ ion exhibits a coordination number $(\mathrm{CN})$ equal to 8 . For $\mathrm{Gd}(1)$, a value of 0.307 was obtained and associated with a square antiprism (SAPR) geometry, the next and closer computed value being 1.733 , which was assigned to a biaugmented trigonal prism (BTPR) geometry (Table 3). Hence, these calculated values allow us to assign the $\mathrm{D}_{4 \mathrm{~d}}$ symmetry to the $\mathrm{Gd}(1)$ ion in complex $\mathbf{1}$ (Table 3 ). 
Table 2. Selected hydrogen-bonding interactions in $\mathbf{1}^{\mathrm{a}}$.

\begin{tabular}{|c|c|c|c|c|}
\hline D-H·A & D-H/Å & $\mathbf{H} \cdot \mathbf{A} / \mathbf{A}$ & $\mathbf{D} \cdot \mathbf{A} / \mathrm{A}$ & $(\mathrm{DHA}) /^{\circ}$ \\
\hline $\mathrm{N}(1)-\mathrm{H}(1) \cdots \mathrm{O}(8 \mathrm{f})$ & 0.880 & $2.12(1)$ & $2.982(1)$ & $165.4(1)$ \\
\hline $\mathrm{N}(3)-\mathrm{H}(3) \cdots \mathrm{O}(4 \mathrm{a})$ & 0.880 & $1.89(1)$ & $2.763(1)$ & $175.6(1)$ \\
\hline $\mathrm{N}(10)-\mathrm{H}(10) \cdots \mathrm{O}(2 \mathrm{~g})$ & 0.880 & $1.92(1)$ & $2.785(1)$ & $168.7(1)$ \\
\hline $\mathrm{O}(1 \mathrm{w})-\mathrm{H}(1 \mathrm{wA}) \cdots \mathrm{O}(7)$ & 0.951 & $2.05(1)$ & $2.986(1)$ & $168.4(1)$ \\
\hline $\mathrm{O}(1 \mathrm{w})-\mathrm{H}(1 \mathrm{wB}) \cdots \mathrm{O}(4 \mathrm{a})$ & 0.953 & $1.77(1)$ & $2.677(1)$ & $159.1(1)$ \\
\hline $\mathrm{O}(2 \mathrm{w})-\mathrm{H}(2 \mathrm{wA}) \cdots \mathrm{O}(2 \mathrm{~g})$ & 0.948 & $1.75(1)$ & 2.691(1) & $169.2(1)$ \\
\hline $\mathrm{O}(3 \mathrm{w})-\mathrm{H}(3 \mathrm{wA}) \cdots \mathrm{O}(11 \mathrm{~b})$ & 0.953 & $2.07(1)$ & $2.944(1)$ & $151.0(1)$ \\
\hline $\mathrm{O}(3 w)-\mathrm{H}(3 w B) \cdots \mathrm{O}(7 w f)$ & 0.950 & $1.76(1)$ & $2.660(1)$ & $156.0(1)$ \\
\hline $\mathrm{O}(4 \mathrm{w})-\mathrm{H}(4 \mathrm{wA}) \cdots \mathrm{O}(10 \mathrm{~b})$ & 0.951 & $2.01(1)$ & $2.870(1)$ & $149.4(1)$ \\
\hline $\mathrm{O}(4 w)-\mathrm{H}(4 w \mathrm{~B}) \cdots \mathrm{O}(15 \mathrm{c})$ & 0.953 & $1.944(1)$ & $2.847(1)$ & $157.4(1)$ \\
\hline $\mathrm{O}(5 \mathrm{w})-\mathrm{H}(5 \mathrm{wA}) \cdots \mathrm{O}(12)$ & 0.950 & $1.77(1)$ & $2.713(1)$ & 169.2(1) \\
\hline $\mathrm{O}(5 \mathrm{w})-\mathrm{H}(5 \mathrm{wB}) \cdots \mathrm{O}(14)$ & 0.950 & $1.87(1)$ & $2.810(1)$ & 169.1(1) \\
\hline $\mathrm{O}(6 \mathrm{w})-\mathrm{H}(6 \mathrm{wA}) \cdots \mathrm{O}(9 \mathrm{~h})$ & 0.951 & $2.27(1)$ & $2.939(1)$ & $126.9(1)$ \\
\hline $\mathrm{O}(6 \mathrm{w})-\mathrm{H}(6 \mathrm{wA}) \cdots \mathrm{O}(7 \mathrm{wf})$ & 0.951 & $2.31(1)$ & $2.986(1)$ & $127.4(1)$ \\
\hline $\mathrm{O}(6 \mathrm{w})-\mathrm{H}(6 \mathrm{wB}) \cdots \mathrm{O}(8 \mathrm{w})$ & 0.953 & $1.75(1)$ & $2.694(1)$ & $171.9(1)$ \\
\hline $\mathrm{O}(7 w)-\mathrm{H}(7 w B) \cdots \mathrm{O}(8 w c)$ & 0.961 & $1.91(1)$ & $2.896(1)$ & $172.5(1)$ \\
\hline $\mathrm{O}(8 \mathrm{w})-\mathrm{H}(8 \mathrm{wA}) \cdots \mathrm{O}(13)$ & 0.954 & $1.91(1)$ & $2.855(1)$ & $170.8(1)$ \\
\hline $\mathrm{O}(8 \mathrm{w})-\mathrm{H}(8 \mathrm{wB}) \cdots \mathrm{O}(15 \mathrm{e})$ & 0.953 & $1.92(1)$ & $2.846(1)$ & 163.9(1) \\
\hline
\end{tabular}

Table 3. Selected values for possible geometries with coordination number $(\mathrm{CN})$ equal to 8 obtained through the SHAPE program and from the structural parameters of complex $\mathbf{1}^{\mathrm{a}}$.

\begin{tabular}{cccccccccc}
\hline HPY & HBPY & CU & SAPR & TDD & JGBF & JETBPY & BTPR & JSD & TT \\
\hline 23.392 & 16.322 & 9.171 & 0.307 & 1.913 & 15.656 & 28.471 & 1.733 & 4.830 & 10.015 \\
\hline
\end{tabular}

${ }^{a}$ HPY: heptagonal pyramid $\left(\mathrm{C}_{7 \mathrm{v}}\right)$; HBPY: hexagonal bipyramid $\left(\mathrm{D}_{6 \mathrm{~h}}\right)$; CU: cube $(\mathrm{Oh}) ; \mathrm{SAPR}$ square antiprism $\left(\mathrm{D}_{4 \mathrm{~d}}\right)$; TDD: triangular dodecahedron $\left(\mathrm{D}_{2 \mathrm{~d}}\right)$; JGBF: Johnson gyrobifastigium $\left(\mathrm{D}_{2 \mathrm{~d}}\right)$; JETBPY: Johnson elongated triangular bipyramid $\left(\mathrm{D}_{3 \mathrm{~h}}\right)$; BTPR: biaugmented trigonal prism $\left(\mathrm{C}_{2 \mathrm{v}}\right)$; JSD: snub disphenoid $\left(\mathrm{D}_{2 \mathrm{~d}}\right)$; TT: triakis tetrahedron (Td).

\subsection{Analysis of the Hirshfeld Surfaces}

Hirshfeld surfaces of the cationic $\left[\mathrm{Gd}(\text { thy })_{2}\left(\mathrm{H}_{2} \mathrm{O}\right)_{6}\right]^{3+}$ complex were calculated, and its closer intermolecular interactions were analyzed through the CrystalExplorer program [29,30]. These surfaces were mapped taking into account the distance from a point on the surface to the nearest atom outside $\left(d_{\mathrm{e}}\right)$ and inside $\left(d_{\mathrm{i}}\right)$ the surface. To overcome limitations related to the size of atoms, a normalized contact distance $\left(d_{\text {norm }}\right)$ was also considered $[29,30]$. For compound 1, Hirshfeld surfaces are shown in Figure 4 and Figure S6, where the shorter contacts are displayed using red color [31]. Intermolecular $\mathrm{O} \cdots \mathrm{H}$ contacts between water molecules and between water molecules and carbonyl groups of the thymine molecules are the main interactions detected on the Hirshfeld surface (Figure 4 and Figure S6). The most important $\mathrm{O} \cdots \mathrm{H}$ contacts are those involving $\mathrm{H}$-bonds between non-coordinated and coordinated water molecules, which are approximately $48 \%$ of the complete fingerprint plot, whereas the $\mathrm{O} \cdots \mathrm{H}$ interactions involving non-coordinated water molecules and carbonyl groups are highlighted from the full fingerprint as ca. 19\% of the plot. Finally, additional $\mathrm{N} \cdots \mathrm{H}$ contacts involving non-coordinated water molecules and $\mathrm{N}-\mathrm{H}$ groups of the thymine molecules only cover approximately $2 \%$ of the fingerprint plot (Figure 4 ).

\subsection{Magnetic Properties}

Dc magnetic susceptibility measurements were carried out on a freshly prepared microcrystalline sample of $\mathbf{1}$ in the $2-300 \mathrm{~K}$ temperature range and under an external magnetic field of $0.5 \mathrm{~T}$. The $\chi_{\mathrm{M}} T$ vs. $T$ plot $\left(\chi_{\mathrm{M}}\right.$ being the molar magnetic susceptibility per Gd ${ }^{\mathrm{III}}$ ion) for compound $\mathbf{1}$ is given in Figure 5. At room temperature, the $\chi_{\mathrm{M}} T$ value is ca. $7.89 \mathrm{~cm}^{3} \mathrm{~mol}^{-1} \mathrm{~K}$, which is very close to that expected for a magnetically isolated Gd ${ }^{\mathrm{III}}$ ion $\left(4 \mathrm{f}^{7}\right.$ ion with $g_{\mathrm{Gd}}=2.0, \mathrm{~S}_{\mathrm{Gd}}=7 / 2$ and $\left.\mathrm{L}_{\mathrm{Gd}}=0\right)$, that is, $7.88 \mathrm{~cm}^{3} \mathrm{~mol}^{-1} \mathrm{~K}[26,32]$. Upon 
cooling, the $\chi_{M} T$ value approximately follows the Curie law to ca. $25 \mathrm{~K}$ with decreasing temperature, before $\chi_{\mathrm{M}} T$ decreases, reaching a minimum value of ca. $7.21 \mathrm{~cm}^{3} \mathrm{~mol}^{-1} \mathrm{~K}$ at $2 \mathrm{~K}$. The decrease of the $\chi_{\mathrm{M}} T$ value observed for complex 1 would likely be assignable to intermolecular interactions and/or very small zero-field splitting (ZFS) effects [32].

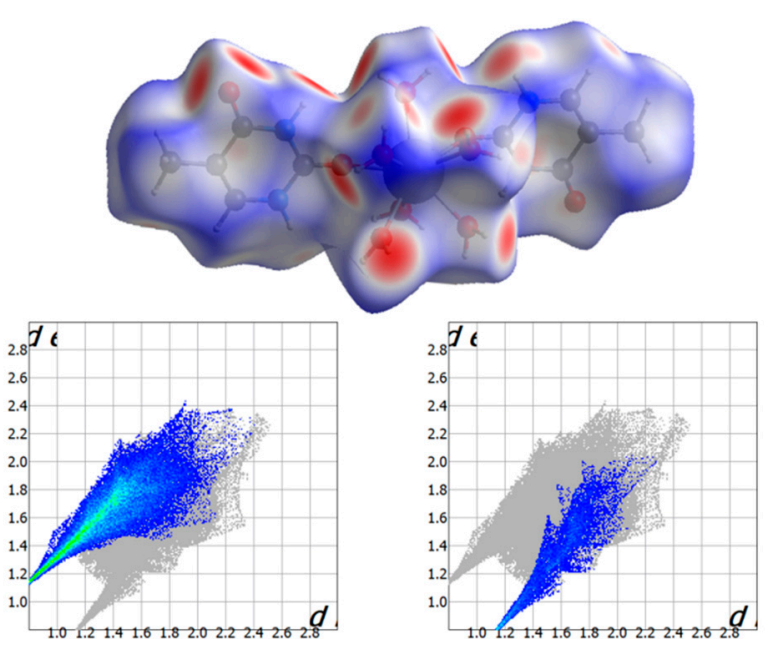

Figure 4. (Top) Hirshfeld surface mapped with $d_{\text {norm }}$ function for 1; (bottom) Fingerprint plots for 1; (bottom, left) Intermolecular $\mathrm{O} \cdots \mathrm{H}$ contacts between non-coordinated and coordinated water molecules are highlighted from the full fingerprint; (bottom, right) Non-coordinated water molecules and thymine carbonyl groups are highlighted from the full fingerprint.

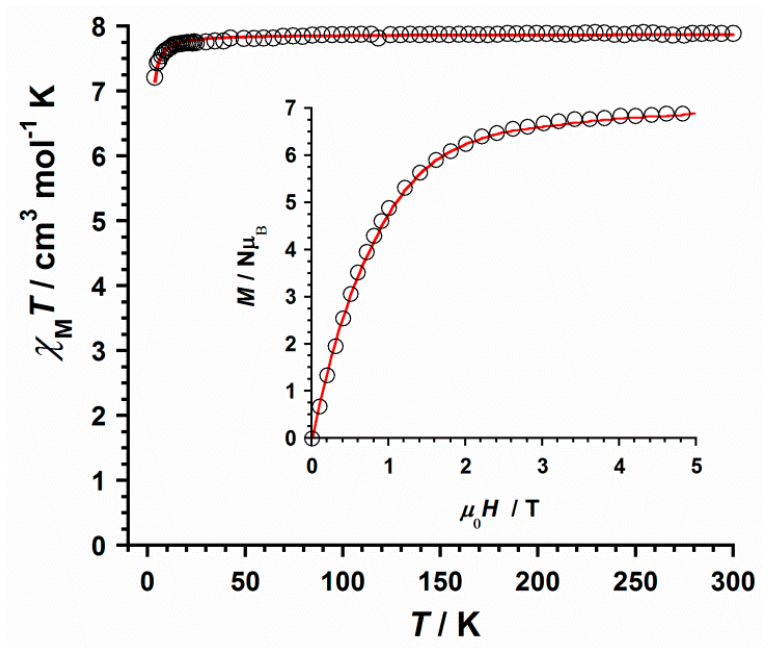

Figure 5. $\chi_{\mathrm{M}} T$ vs. $T$ plot obtained for compound 1 . The inset shows the field dependence of the molar magnetization $(M)$ plot at $2.0 \mathrm{~K}$ for 1 . The solid red lines represent the best fit of the experimental data.

To analyze the magnetic behavior and fit the experimental data of the $\chi_{M} T$ vs. $T$ plot for complex 1 , the theoretical expression for the magnetic susceptibility of a single and isotropic $\mathrm{S}_{\mathrm{Gd}}=7 / 2$ center was used $\left[\mathrm{X}_{\mathrm{M}}=\left(\mathrm{N}_{\mathrm{B}^{2}}{ }^{2} g_{\mathrm{Gd}}{ }^{2} / 3 \mathrm{k}_{\mathrm{B}}\right) \mathrm{S}_{\mathrm{Gd}}\left(\mathrm{S}_{\mathrm{Gd}}+1\right) /(T-\Theta)\right]$ [25]. Due to possible intermolecular interactions that can take place in 1 , a $\Theta$ parameter was also included in this expression. The best least-squares fit gave the parameters $g_{\mathrm{Gd}}=2.008$ (1) and $\Theta=-0.039(1) \mathrm{K}$ with $R=1.9 \times 10^{-5}$ for $\mathbf{1}\{R$ being the agreement factor defined as $\left.\Sigma_{\mathrm{i}}\left[\left(\chi_{\mathrm{M}} T\right)_{\mathrm{i}}{ }^{\text {obs }}-\left(\chi_{\mathrm{M}} T\right)_{\mathrm{i}}{ }^{\text {calcd }}\right]^{2} /\left[\left(\chi_{\mathrm{M}} T\right)_{\mathrm{i}}{ }^{\text {obs }}\right]^{2}\right\}$.

Field dependence of the molar magnetization $(M)$ plot for $\mathbf{1}$ at $2 \mathrm{~K}$ is given in the inset of Figure 5. This plot exhibits a continuous increase of $M$ with the applied magnetic field, showing a maximum value of $M$ obtained for $\mathbf{1}$ (ca. $6.92 \mu_{\mathrm{B}}$ ) at $5.0 \mathrm{~T}$, which is as expected for a mononuclear $\mathrm{Gd}^{\mathrm{III}}$ complex [25]. The experimental data of the $M$ vs. $H$ plot were 
close to the Brillouin curve generated, with values of $g$ and $S$ of 2.0 and 7/2, respectively (Figure 5) [32].

\subsection{MR Imaging Phantom Studies}

The relaxometric properties of compound $\mathbf{1}$ as a potential high-field MR imaging contrast agent were evaluated [33]. Thirteen samples of $\mathbf{1}$ were prepared in physiological serum with concentrations covering the range of $0.0-3.2 \mathrm{mM}$ and were measured on a clinical MR scanner (Achieva 3T TX, Philips Healthcare, Best, The Netherlands) by using the volumetric head eight channels SENSE coil (Figure 6 and Figure S7).

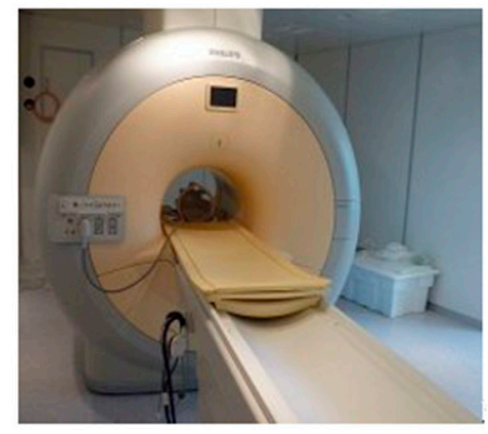

(a)

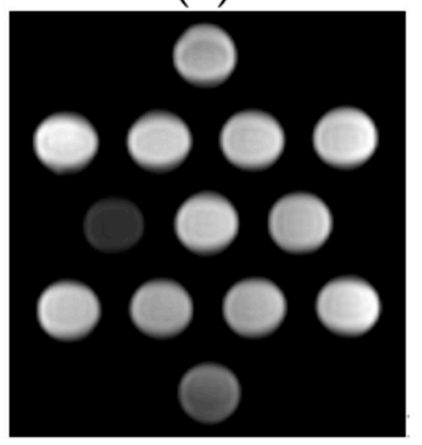

(c)

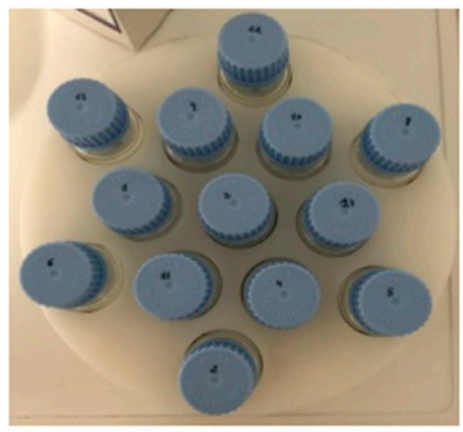

(b)

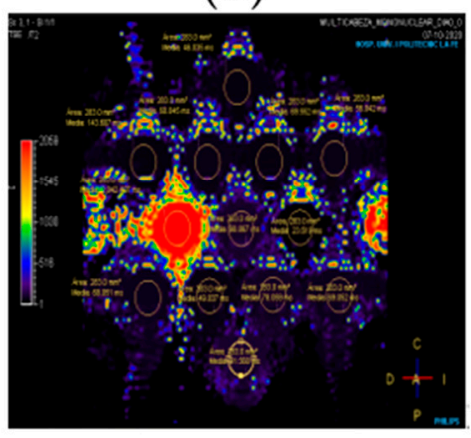

(d)

Figure 6. (a) MR imaging scanner (Philips Achieva 3T); (b) Samples of 1 prepared in physiological serum with concentrations covering the range of $0.0-3.2 \mathrm{mM}$; (c) MR images of the tube phantoms of $\mathbf{1}$; (d) $\mathrm{T}_{2}$ parametric map analysis.

The relaxation rate, denoted by $R$ (and expressed in $\mathrm{s}^{-1}$ ), was obtained for each concentration through the calculation of the corresponding relaxation time T. $R_{1}$ was obtained by calculating the $\mathrm{T}_{1}$ time from FFE sequences with $2^{\circ}, 5^{\circ}, 10^{\circ}, 15^{\circ}, 25^{\circ}$, and $45^{\circ}$ flip angles, whereas $r_{2}$ and $r_{2}{ }^{*}$ values were obtained after calculating $\mathrm{T}_{2}$ and $\mathrm{T}_{2}{ }^{*}$ relaxation times from TSE and GRE sequences with 32 echo times each, $\mathrm{TE}_{1}=10 \mathrm{~ms}, \Delta \mathrm{TE}=10 \mathrm{~ms}$ and TE1 $=0.9 \mathrm{~ms}, \Delta \mathrm{TE}=0.7 \mathrm{~ms}$, respectively [34]. Thus, the longitudinal relaxivity $\left(r_{1}\right)$ of 1 at $3 \mathrm{~T}$ was determined to be $16.1 \mathrm{mM}^{-1} \mathrm{~s}^{-1}$, whereas the transversal relaxivities $r_{2}$ and $r_{2}{ }^{*}$ values were 13.5 and $14.5 \mathrm{mM}^{-1} \mathrm{~s}^{-1}$, respectively (Figures 7 and 8). These results show relaxivity values for 1 that are much higher than those of commercial MR imaging contrast agents currently employed on 3 T equipment [33], such as Magnevist, Gadovist, Prohance, Multihance, Dotarem, and Omniscan, among others [34], which makes 1 potentially useful. The fact that the GdIII ion in $\mathbf{1}$ exhibits a higher number of coordinate water molecules than the typical commercial contrast agents would enhance, at least in part, the common relaxivity values reported for these commercial contrast agents [34]. 


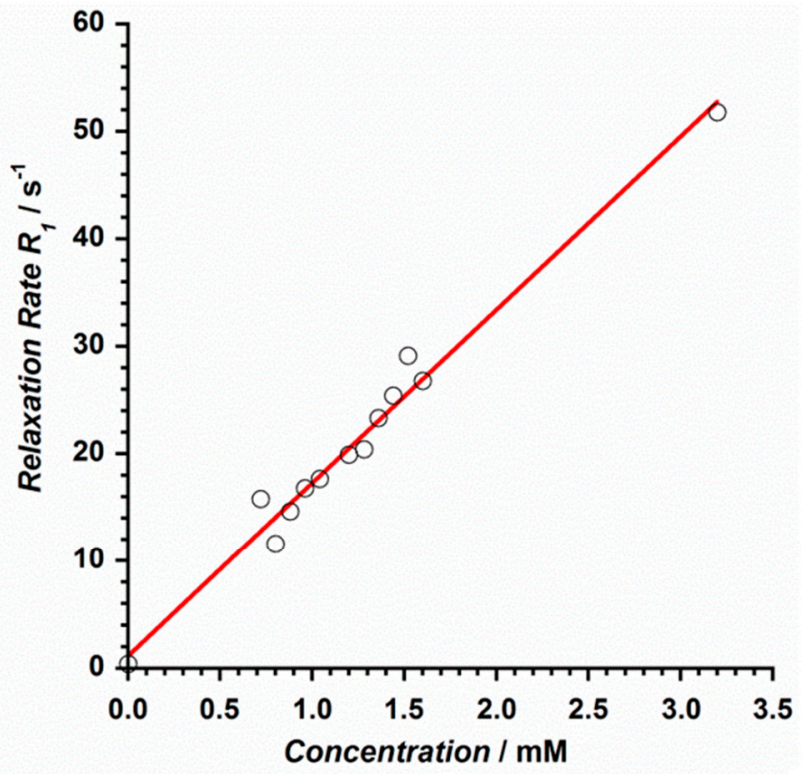

(a)

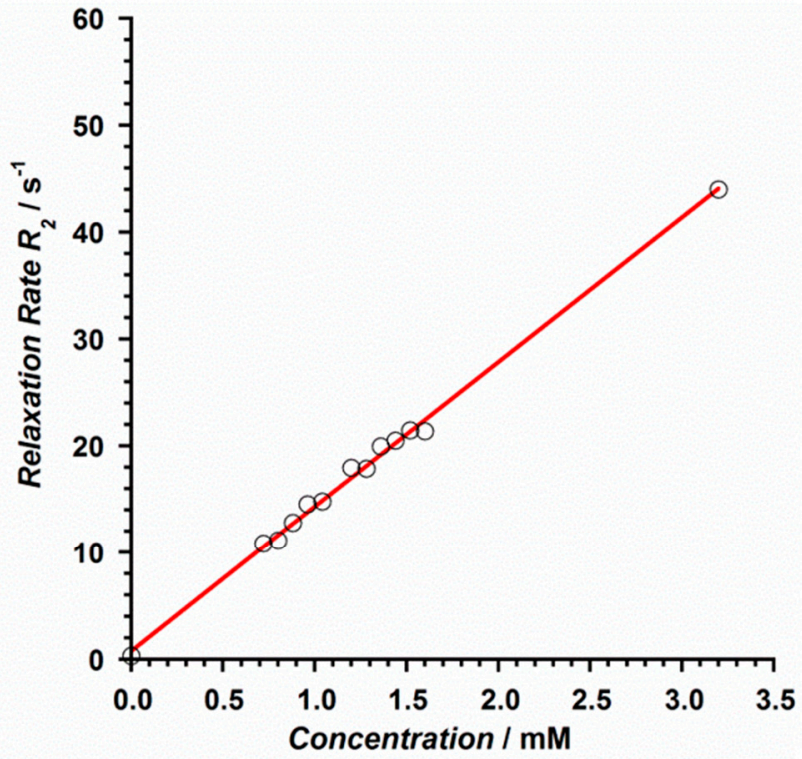

(b)

Figure 7. Relaxation rate vs. contrast concentration plot obtained for the relaxivities $r_{1}(\mathbf{a})$ and $r_{2}(\mathbf{b})$ of compound $\mathbf{1}$. The red line represents the best linear fit of the experimental data.

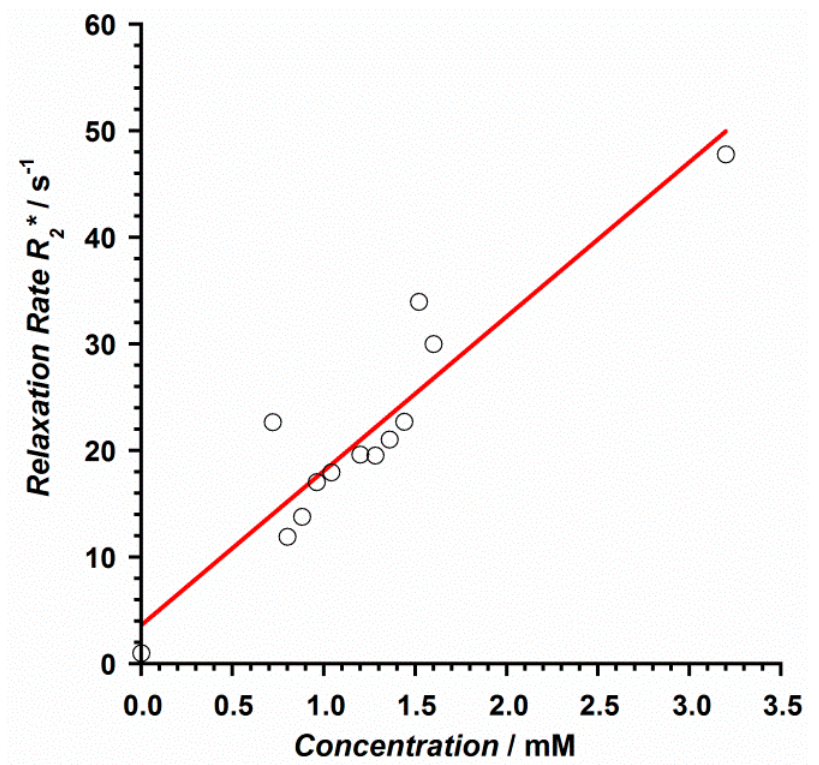

Figure 8. Relaxation rate vs. contrast concentration plot obtained for the relaxivity $r_{2}{ }^{*}$ of compound 1. The red line represents the best linear fit of the experimental data.

\section{Materials and Methods}

\subsection{Reagents and Instruments}

All of the manipulations were performed under aerobic conditions. All the commercial chemicals were used as received. CAUTION: Although no problems were encountered in this work, care should be taken when using the potentially explosive perchlorate anion $\left(\mathrm{ClO}_{4}^{-}\right)$.

Elemental analyses $(\mathrm{C}, \mathrm{H}, \mathrm{N})$ and $\mathrm{X}$-ray microanalysis were performed by the Central Service for the Support to Experimental Research (SCSIE) at the University of Valencia. Scanning electron microscopy (SEM) images and results were obtained from a Hitachi S-4800 field emission scanning electron microscope (Hitachi Ltd., Tokyo, Japan). The electronic absorption spectra of $\mathbf{1}$ and thymine were measured at room temperature in 
a Jasco V-670 UV-vis-NIR spectrophotometer (Jasco Ltd., Tokyo, Japan) in the range of 600 to $1400 \mathrm{~nm}$. Infrared spectra (IR) of $\mathbf{1}$ and thymine were recorded with a PerkinElmer Spectrum 65 FT-IR spectrometer (PerkinElmer Inc., Waltham, USA) in the range of 400 to $4000 \mathrm{~cm}^{-1}$. Variable-temperature, solid-state direct current (DC) magnetic susceptibility data down to $2.0 \mathrm{~K}$ were collected on a Quantum Design MPMS-XL SQUID magnetometer (Quantum Design, Inc., San Diego, CA, USA) equipped with a 5 T DC magnet. The experimental magnetic data were corrected for the diamagnetic contributions of the constituent atoms and also for the sample holder. MR data were collected on a Philips Achieva 3T clinical scanner (Philips Healthcare, Best, The Netherlands) with a volumetric head eight channels SENSE coil at La Fe University and Polytechnic Hospital.

\subsection{Preparation of Compound}

Synthesis of $\left[\mathrm{Gd}(\text { thy })_{2}\left(\mathrm{H}_{2} \mathrm{O}\right)_{6}\right]\left(\mathrm{ClO}_{4}\right)_{3} \cdot 2 \mathrm{H}_{2} \mathrm{O}(1)$

A mixture of $\mathrm{Gd}_{2} \mathrm{O}_{3}(0.091 \mathrm{~g}, 0.25 \mathrm{mmol})$ and thymine $(0.063 \mathrm{~g}, 0.50 \mathrm{mmol})$ in an aqueous suspension $(5 \mathrm{~mL})$ was acidulated with perchloric acid $(1.0 \mathrm{~mL}, 2 \mathrm{M})$ and was stirred and heated at $60^{\circ} \mathrm{C}$ for $1 \mathrm{~h}$. The resulting solution was left to evaporate at room temperature for 1 week. Colorless parallelepipeds were obtained and were suitable for single-crystal X-ray diffraction studies. Yield: ca. $45 \%$. Anal. Calcd. for $\mathrm{C}_{10} \mathrm{H}_{24} \mathrm{~N}_{4} \mathrm{O}_{22} \mathrm{Cl}_{3} \mathrm{Gd}$ : C, $14.7 ; \mathrm{H}$, 3.0; N, 6.9. Found: $\mathrm{C}, 14.5 ; \mathrm{H}, 3.0 ; \mathrm{N}, 6.8$. SEM-EDAX: a molar ratio of $1: 3$ for $\mathrm{Gd} / \mathrm{Cl}$ was found for 1. IR ( $\mathrm{KBr}$ pellet $\left./ \mathrm{cm}^{-1}\right)$ : peaks were observed at $3399(\mathrm{br}), 3218(\mathrm{~m}), 3063(\mathrm{~m})$, $2928(\mathrm{~m}), 2813(\mathrm{~m}), 1747(\mathrm{~s}), 1679(\mathrm{vs}), 1635(\mathrm{~m}), 1483(\mathrm{w}), 1449(\mathrm{~m}), 1427(\mathrm{w}), 1383(\mathrm{~m})$, 1246 (m), 1205 (m), 1145 (vs), 1112 (vs), 1089 (vs), 935 (m), $835(\mathrm{~m}), 815(\mathrm{~m}), 760(\mathrm{~m}), 744(\mathrm{~m})$, 627 (vs), $560(\mathrm{~m}), 477(\mathrm{~m}), 432(\mathrm{~m})$.

\subsection{X-ray Data Collection and Structure Refinement}

X-ray diffraction data from a single crystal of 1 with dimensions $0.34 \times 0.12 \times 0.05 \mathrm{~mm}^{3}$ was collected on a Bruker D8 Venture diffractometer (Bruker, Billerica, MA, USA) with graphite-monochromated Mo-K $\mathrm{K}_{\alpha}$ radiation $(\lambda=0.71073 \AA)$. The structures were solved by standard direct methods and subsequently completed by Fourier recycling by using the SHELXTL software packages. The obtained model was refined with version 2018/1 of SHELXL against $F^{2}$ on all data by full-matrix least squares [35]. All non-hydrogen atoms were anisotropically refined, whereas the hydrogen atoms of the thymine molecules were set in calculated positions and refined isotropically by using the riding model. The graphical manipulations were performed with the DIAMOND program [36]. The CCDC code for 1 is 2009091.

\section{Conclusions}

In summary, the preparation, crystal structure, magnetic properties, and MR imaging phantom studies of a novel Gd ${ }^{\mathrm{III}}$ complex based on the thymine nucleobase, of formula $\left[\mathrm{Gd}(\text { thy })_{2}\left(\mathrm{H}_{2} \mathrm{O}\right)_{6}\right]\left(\mathrm{ClO}_{4}\right)_{3} \cdot 2 \mathrm{H}_{2} \mathrm{O}(\mathbf{1})$ [thy = thymine], have been reported. 1 displays the first reported crystal structure based on gadolinium and thymine. Furthermore, $\mathbf{1}$ exhibits high relaxivity values and, therefore, can be considered a suitable candidate for further developments and MR analysis. Given that most of the thymine-containing complexes have been reported with this ligand in the form of thyminate anion, we presented in this work a singular strategy to prepare lanthanide compounds where the thymine molecule acts as a neutral ligand toward the metal ion. Further investigations dealing with the synthesis and characterization of this type of lanthanide complexes are now in progress in our group, incorporating other $4 \mathrm{f}$ ions and similar biomolecules.

Supplementary Materials: The following are available online at https:/ / www.mdpi.com/article/10 .3390/ijms22094586/s1, X-ray crystallographic data in CIF format for compound 1, Figures S1-S7, and Table S1. 
Author Contributions: L.M.-B. and J.M.-L. conceived the idea and obtained funding for the project. M.O.-A. carried out the synthesis, the UV-vis-NIR measurements, the X-ray data collection, and the calculations through the SHAPE and CrystalExplorer programs. S.G.-C. and A.T.-E. performed the acquisition of the MR images, the phantoms, and the parametric map analysis. A.T.-E., L.M.-B., I.C., and J.M.-L. analyzed the data associated with all the experiments and wrote the manuscript, which all authors discussed and commented on. All authors have read and agreed to the published version of the manuscript.

Funding: This research was funded by the VLC-BIOMED Program (2017) of the University of Valencia [Subprogram A “Ayudas para el fomento de acciones preparatorias coordinadas UV-HUP/IIS La $F e^{\prime \prime}$, Project 11-2017-A] and the Spanish Ministry of Science, Innovation and Universities [Project PID2019-109735GB-I00 and CEX2019-000919-M (Excellence Unit “María de Maeztu”)].

Institutional Review Board Statement: Not applicable.

Informed Consent Statement: Not applicable.

Data Availability Statement: The reported data are available on request from the corresponding author.

Acknowledgments: The authors thank Nicolás Moliner for assistance in SQUID measurements. M.O.-A. and J.M.-L. thank the Spanish "FPI fellowships" and "Ramón y Cajal" Programmes, respectively.

Conflicts of Interest: The authors declare no conflict of interest.

\section{References}

1. Lippert, B.; Sanz Miguel, P.J. The renaissance of metal-pyrimidine nucleobase coordination chemistry. Acc. Chem. Res. 2016, 49, 1537-1545. [CrossRef] [PubMed]

2. Somerville, R.L. Encyclopedia of Genetics; Academic Press: San Diego, CA, USA, 2001; pp. 1965-1966.

3. Park, H.J.; Zhang, K.; Ren, Y.; Nadji, S.; Sinha, N.; Taylor, J.-S.; Kang, C.H. Crystal structure of a DNA decamer containing a cis-syn thymine dimer. Proc. Natl. Acad. Sci. USA 2002, 99, 15965-15970. [CrossRef]

4. Sakate, M.; Hosoda, H.; Suzuki, T. Crystal structures of bis-[2-(pyridin-2-yl)phenyl- $\left.{ }^{2} \mathrm{~N}, \mathrm{C}^{1}\right]$ rhodium(III) complexes containing an acetonitrile or monodentate thyminate(1-) ligand. Acta Cryst. 2016, E72, 543-547. [CrossRef] [PubMed]

5. Vegas, V.G.; Lorca, R.; Latorre, A.; Hassanein, K.; Gómez-García, C.J.; Castillo, O.; Somoza, A.; Zamora, F.; Amo-Ochoa, P. Copper(II)-thymine coordination polymer nanoribbons as potential oligonucleotide nanocarriers. Angew. Chem. Int. Ed. 2017, 56, 987-991. [CrossRef] [PubMed]

6. $\quad$ Correa, R.S.; Freire, V.; Barbosa, M.I.F.; Bezerra, D.P.; Bomfim, L.M.; Moreira, D.R.M.; Soares, M.B.P.; Ellena, J.; Batista, A.A. $\mathrm{Ru}(\mathrm{II})$-thyminate complexes: New metallodrug candidates against tumor cells. New J. Chem. 2018, 42, 6794-6802. [CrossRef]

7. Silva, S.L.R.; Baliza, I.R.S.; Dias, R.B.; Sales, C.B.S.; Rocha, C.A.G.; Soares, M.B.P.; Correa, R.S.; Batista, A.A.; Bezerra, D.P. $\mathrm{Ru}(\mathrm{II})$-thymine complex causes DNA damage and apoptotic cell death in human colon carcinoma HCT116 cells mediated by JNK/p38/ERK1/2 via a p53-independent signaling. Sci. Rep. 2019, 9, 11094. [CrossRef]

8. De, H.; Paul, A.; Datta, A. Theoretical study of $\mathrm{Au}_{4}$ thymine, $\mathrm{Au}_{20}$ and $\mathrm{Ag}_{20}$ uracil and thymine complexes for surface enhanced Raman scattering. Comput. Theor. Chem. 2017, 1111, 1-13. [CrossRef]

9. Kondo, J.; Yamada, T.; Hirose, C.; Okamoto, I.; Tanaka, Y.; Ono, A. Crystal structure of metallo DNA duplex containing consecutive Watson-Crick-like T-Hg(II)-T base pairs. Angew. Chem. Int. Ed. 2014, 24, 2385-2388. [CrossRef]

10. Yamaguchi, H.; Šebera, J.; Kondo, J.; Oda, S.; Komuro, T.; Kawamura, T.; Dairaku, T.; Kondo, Y.; Okamoto, I.; Ono, A.; et al. The structure of metallo-DNA with consecutive thymine- $\mathrm{Hg}$ II -thymine base pairs explains positive entropy for the metallo base pair formation. Nucleic Acids Res. 2014, 42, 4094-4099. [CrossRef]

11. Kuriyama, M.; Haruta, K.; Dairaku, T.; Kawamura, T.; Kikkawa, S.; Inamoto, K.; Tsukamoto, H.; Kondo, Y.; Torigoe, H.; Okamoto, I.; et al. $\mathrm{Hg}^{2+}$-trapping beads: $\mathrm{Hg}^{2+}$-specific recognition through thymine-Hg(II)-thymine base pairing. Chem. Pharm. Bull. 2014, 62, 709-712. [CrossRef]

12. Li, L.; Wen, Y.; Xu, L.; Xu, Q.; Song, S.; Zuo, X.; Yan, J.; Zhang, W.; Liu, G. Development of mercury (II) ion biosensors based on mercury-specific oligonucleotide probes. Biosens. Bioelectron. 2016, 75, 433-445. [CrossRef] [PubMed]

13. Chun, H.J.; Kim, S.; Han, Y.D.; Kim, D.W.; Kim, K.R.; Kim, H.S.; Kim, J.H.; Yoon, H.C. Water-soluble mercury ion sensing based on the thymine- $\mathrm{Hg}^{2+}$-thymine base pair using retroreflective Janus particle as an optical signaling probe. Biosens. Bioelectron. 2018, 104, 138-144. [CrossRef] [PubMed]

14. Kashima, A.; Sakate, M.; Ota, H.; Fuyuhiro, A.; Sunatsukia, Y.; Suzuki, T. Thyminate(2-)-bridged cyclic tetranuclear rhodium(III) complexes formed by a template of a sodium, calcium or lanthanoid ion. Chem. Commun. 2015, 51, 1889-1892. [CrossRef] [PubMed]

15. Armentano, D.; Marino, N.; Mastropietro, T.F.; Martínez-Lillo, J.; Cano, J.; Julve, M.; Lloret, F.; De Munno, G. Self-assembly of a chiral carbonate- and cytidine-containing dodecanuclear Copper(II) Complex: A multiarm-supplied globular capsule. Inorg. Chem. 2008, 47, 10229-10231. [CrossRef] [PubMed] 
16. Martínez-Lillo, J.; Mastropietro, T.F.; Lappano, R.; Madeo, A.; Alberto, M.E.; Russo, N.; Maggiolini, M.; De Munno, G. Rhenium(IV) compounds inducing apoptosis in cancer cells. Chem. Commun. 2011, 47, 5283-5285. [CrossRef]

17. Marino, N.; Armentano, D.; Mastropietro, T.F.; Julve, M.; De Munno, G.; Martínez-Lillo, J. Cubane-Type Cu ${ }_{4}{ }_{4}$ and $\mathrm{Mn}_{2}{ }_{2} \mathrm{Mn}^{\mathrm{III}}{ }_{2}$ complexes based on pyridoxine: A versatile ligand for metal assembling. Inorg. Chem. 2013, 52, 11934-11943. [CrossRef]

18. Armentano, D.; Barquero, M.A.; Rojas-Dotti, C.; Moliner, N.; De Munno, G.; Brechin, E.K.; Martínez-Lillo, J. Enhancement of intermolecular magnetic exchange through halogen $\cdots$ halogen interactions in bisadeninium rhenium(IV) salts. Cryst. Growth Des. 2017, 17, 5342-5348. [CrossRef]

19. Orts-Arroyo, M.; Castro, I.; Lloret, F.; Martínez-Lillo, J. Field-induced slow relaxation of magnetisation in two one-dimensional homometallic dysprosium(III) complexes based on alpha- and beta-amino acids. Dalton Trans. 2020, 49, 9155-9163. [CrossRef]

20. Orts-Arroyo, M.; Castro, I.; Martínez-Lillo, J. Detection of Hypoxanthine from inosine and unusual hydrolysis of immunosuppressive drug azathioprine through the formation of a diruthenium(III) system. Biosensors 2021, 11, 19. [CrossRef] [PubMed]

21. Colarusso, P.; Zhang, K.-Q.; Guo, B.; Bernath, P.F. The infrared spectra of uracil, thymine, and adenine in the gas phase. Chem. Phys. Lett. 1997, 269, 39-48. [CrossRef]

22. Singh, J.S. FTIR and Raman spectra and fundamental frequencies of biomolecule: 5-Methyluracil (thymine). J. Mol. Struct. 2008, 876, 127-133. [CrossRef]

23. Azab, H.A.; Al-Deyab, S.S.; Anwar, Z.M.; El-Gawad, I.I.A.; Kamel, R.M. Comparison of the coordination tendency of amino acids, nucleobases, or mononucleotides toward the monomeric and dimeric lanthanide complexes with biologically important compounds. J. Chem. Eng. Data 2011, 56, 2613-2625. [CrossRef]

24. Guillou, O.; Bergerat, P.; Kahn, O.; Bakalbassis, E.; Boubekeur, K.; Batail, P.; Guillot, M. Ferromagnetically coupled gadolinium(III)copper(II) molecular material. Inorg. Chem. 1992, 31, 110-114. [CrossRef]

25. Cañadillas-Delgado, L.; Fabelo, O.; Cano, J.; Ruiz-Pérez, C. Magnetic Interactions in Oxo-Carboxylate Bridged Gadolinium(III) Complexes Synthesis, Crystal Structures and Magnetic Properties; Nova Science Publishers, Inc.: Hauppauge, NY, USA, 2010.

26. Martínez-Lillo, J.; Cañadillas-Delgado, L.; Cano, J.; Lloret, F.; Julve, M.; Faus, J. A heteropentanuclear oxalato-bridged [Re ${ }^{\mathrm{IV}}{ }_{4} \mathrm{Gd}^{\mathrm{III}}$ ] complex: Synthesis, crystal structure and magnetic properties. Chem. Commun. 2012, 48, 9242-9244. [CrossRef] [PubMed]

27. Portalone, G.; Bencivenni, L.; Colapietro, M.; Pieretti, A.; Ramondo, F. The Effect of hydrogen bonding on the structures of uracil and some methyl derivatives studied by experiment and theory. Acta Chem. Scand. 1999, 53, 57-68. [CrossRef]

28. Llunell, M.; Casanova, D.; Cirera, J.; Alemany, P.; Alvarez, S. SHAPE 2.1; Universitat de Barcelona: Barcelona, Spain, 2013.

29. Spackman, M.A.; Jayatilaka, D. Hirshfeld surface analysis. CrystEngComm 2009, 11, 19-32. [CrossRef]

30. Turner, M.J.; McKinnon, J.J.; Wolff, S.K.; Grimwood, D.J.; Spackman, P.R.; Jayatilaka, D.; Spackman, M.A. Crystal Explorer 17; University of Western Australia: Perth, Australia, 2017.

31. Orts-Arroyo, M.; Castro, I.; Lloret, F.; Martínez-Lillo, J. Molecular self-assembly in a family of oxo-bridged dinuclear ruthenium(IV) systems. Cryst. Growth Des. 2020, 20, 2044-2056. [CrossRef]

32. Kahn, O. Molecular Magnetism; VCH: New York, NY, USA, 1993.

33. Mousavi, B.; Chauvin, A.-S.; Moriggi, L.; Helm, L. Carbazole as linker for dinuclear gadolinium-based MRI contrast agents. Eur. J. Inorg. Chem. 2017, 5403-5412. [CrossRef]

34. Rohrer, M.; Bauer, H.; Mintorovitch, J.; Requardt, M.; Weinmann, H.-J. Comparison of magnetic properties of MRI contrast media solutions at different magnetic field strengths. Investig. Radiol. 2005, 40, 715-724. [CrossRef] [PubMed]

35. Bruker Analytical X-ray Instruments. SHELXL-2018/1; Bruker Analytical X-ray Instruments: Madison, WI, USA, 2018.

36. Crystal Impact GbR. DIAMOND 4.5.0; Crystal Impact GbR: Bonn, Germany, 2018. 